\title{
sciendo

\section{Factors Affecting Energy-Efficient Household Products Buying Intention: Empirical Study}

\author{
Syed S. ALAM ${ }^{1 *}$, Chieh-Yu LIN ${ }^{2}$, Maisarah AHMAD ${ }^{3}$, Nor A. OMAR ${ }^{4}$, Mohd H. ALI ${ }^{4}$ \\ ${ }^{1}$ Faculty of Business, Finance and Hospitality, Mahsa University, Jln SP 2, Bandar Saujana Putra, \\ Jenjarom, Selangor, 42610, Malaysia \\ ${ }^{2}$ College of Management, Chang Jung Christian University, Tainan, 71101, Taiwan \\ ${ }^{3}$ Department of Management and Humanities, Faculty of Sciences and Information Technology, \\ Universiti Teknologi PETRONAS, Persiaran UTP, Seri Iskander, Perak, 32610, Malaysia \\ ${ }^{4}$ Faculty of Economics and Management, Universiti Kebangsaan Malaysia, \\ UKM Bangi, Selangor, 43600, Malaysia
}

\begin{abstract}
The aim of this study is to identify the factors affecting behavioural intention in buying energy-efficient household products in Malaysia. The extended Theory of Planned Behaviour (TPB) was tested in this research. Five hypotheses were tested using data derived from 336 residences in Malaysia. The hypothesized model incorporates knowledge and reasonable price into the conventional (TPB) model. Multiple regression analysis was used to examine the relationship between the independent and dependent variables. The results of the multiple regression analysis show that attitude, subjective norm, perceived behavioural control, knowledge and reasonable price have significant and positive effect on energyefficient household product buying intention among residences in Malaysia. This research results provide insights for companies for promotion of green technological products and in strategizing to motivate residence in Malaysia to embrace green consumption behaviour.
\end{abstract}

Keywords - Cleaner product; Malaysia; residence; TPB

\section{INTRODUCTION}

Nowadays environmental issues and concerns are widely accepted and considered [1]. Due to the environmental degradation globally, consumers in all over the world have started to understand that their buying behaviour is the root of environmental problems [2]. According to Paco and Raposo [3], Barber [4] and Okada and Mais [5] consumers are now willing to change their behaviour in green context due to increasing awareness of health issues, global warming, climate change and environmental matters. Major changes are being required of energy infrastructure as it faces the serious challenges of protecting the climate, reducing pollution, and securing energy. Due to concern about climate change and energy security, companies are now producing environment-friendly products and started to use environmental strategies. Researcher identified that ecological product market demand steadily growing all over the world [6]. Thus, companies are introducing ecological products such as food and cars. Some other ecological products such as reusable and recycling packaging, energy saving bulbs and many other products that are capturing companies' attentions [7].

Consumers attitude have been changing towards acceptance of environmentally friendly products. Companies and academic researchers have realized the importance of environmental issues.

\footnotetext{
* Corresponding author.

E-mail address: shahalam@ukm.edu.my

(C2019 Syed S. Alam, Chieh-Yu Lin, Maisarah Ahmad, Nor A. Omar, Mohd H. Ali.

This is an open access article licensed under the Creative Commons Attribution License (http://creativecommons.org/ licenses/by/4.0), in the manner agreed with Sciendo.
} 
According to Chen and Chai [8] Malaysian government has established some strategies to encourage and promote sustainable consumption practices to Malaysian consumers. In 24 July 2009 Malaysian government has introduced National Green Technology Policy for the Malaysian people [9]. There are four pillars namely Social, Environment, Economy and Energy. Green Technology is the main driver to speed up the national economy and promote sustainable development. Therefore, more attention has drawn to the corporate across in Malaysia on sustainable energy conservation.

The energy demand in Malaysia will increase $4.8 \%$ by 2030 [10]. Malaysia is experiencing rapid economic growth due to the increased number of population, much higher investments in infrastructure development and massive growth of the construction industry. Thus, it is necessary to establish the demand side energy management. Considering the high demand for energy at individual homes, Leelakulthanit [11] stressed that it is important to reduce the exhaustive usage of energy by implementing efficient energy production techniques and efficient energy consumption. Monthly home electricity bill will decrease if home energy management system is implemented and energy efficient product use at home is encouraged. Energy efficiency denotes lesser usage of energy in providing same services or functions.

According to Shila [12], business sectors and government of Malaysia have taken environmental issues seriously. Zainudin's [13] study shows that yearly 30 to 40 environmental services have emerged recently, whereas it was merely there a decade ago. Moisander [14] stated that eco-friendly consumption increased due to awareness of natural issue and environmental protection. There are few studies conducted in this area as it is one of the new issues in Malaysia [13]. Moreover, there is a need for closer examination of energy efficient product buying intention in a specific country. Due to social, economic and cultural differences research findings cannot be generalized and transferred from one country to another country. These arguments led us to conduct this empirical study, which examines household energy efficient electronic product buying behaviour by using extended Theory of Planned Behaviour Model [15]. In this study, Theory of Planned Behaviour (TPB) is used, because it provides the theoretical support and justification in interpreting the results. In addition, this model also identified the predictor variables for energy efficient product buying intention.

\section{THEORETICAL FRAMEWORK}

\subsection{Theory of Planned Behaviour (TPB)}

Human behaviour is explained in TPB model. TPB is used in various field of study such as healthcare, public relation and advertising to examine the relationship among behaviour, behavioural intention, attitudes and beliefs. TPB states that individual's behavioural intentions and behaviour is influence by attitude, subjective norms and perceived behavioural control [15]-[17]. According to Ajzen and Fishbein [16] the central theme of the TPB theory is that actor behaviour is under control which can be anticipated by examining individual's intention to perform certain behaviour. Ajzen [17] stated that intentions are individual motivation, enthusiastic to give effort and intent to work had to enact certain behaviour.

TPB is the extension of theory of reason action (TRA). To improve the predictive power of TRA perceived behavioural control variable added an additional variable. According to Robinson and Smith [18] TPB can assess and evaluate the human behaviour and traits. TRA also can use to test the adoption or rejection of human behavioural traits and reactions. In choosing or purchasing a product TRA has the capability to define attitude. On the other hand, TRA also explains and provides reason to selecting certain type of products by the consumer [19]. Other than two main constructs in TRA i.e. attitude to the behaviour and subjective norms, TPB compliments another variable perceived behavioural control [20]. 


\subsection{Literature Review}

TPB is one of the simple and competent frameworks which is use for examine the individual's intent to perform context-specific actions [21]. According to Taylor and Todd [22] and Ajzen [17] several social psychologies associated and empirical studies have been supported by TPB. A metaanalysis study conducted by Thomson et al. [23] and found that 40-50\% of variance is explained by the measure of attitude, subjective norm and perceived behavioural control in intentions and 19 $\%$ and $38 \%$ of variance explained by behavioural intention.

Researchers like Conner and Sparks [24] and Sparks and Shepherd [25] conducted studies on food choices behaviour of consumers using theory of planned behaviour (TPB). Using habit as an additional independent construct Armitage and Conner [20] conducted study used TPB as a based model. In other food related researches TPB used as the base theory and found TPB is the important model [26], [27].

Cook et al. [28] and Sparks et al. [29] studies in food related behaviour were used theory of planned behaviour (TPB) and confirmed TPB is the important model. In the last 20 years 600 empirical studies have concluded that TPB can be the important theory for any behavioural research. Bonne and Vermeir [30] study used habit as an additional variable with TPB model in halal meat consumption in France. This study confirmed that attitude, subjective norm and perceived behavioural control have significant effect on halal meat consumption.

TPB has been used as the model in other researches include the green product purchase behaviour [31], [32], organic food purchase behaviour [32]-[34], online buying behaviour [35], [36]. Information system researchers [37] and genetically modified food researchers [38] also used TPB in their studies.

Although researcher identified TPB is one of the most powerful models to predict individual behaviour (see review [39]) additional variables are included in many other researches such as knowledge [40] and reasonable price [41]. Ajzen [16] stresses that TPB is open to extend by adding further additional variables. This argument is allowed the researchers adding additional variables within extended TPB model context. Thus, knowledge and reasonable price variables are considered to be worthy in this research.

\section{RESEARCH MODEL AND HYPOTHESIS}

Fig. 1 is the research model developed for this study. The research model used in this study is shown in Fig. 1. Before actual purchase, purchasing intention of energy-efficient product preceded. It is assumed that attitude has direct and positive relationship with behavioural intention. Subjective norms, behavioural control, knowledge and price were also hypothesized as having direct relationships with intention to buy. 


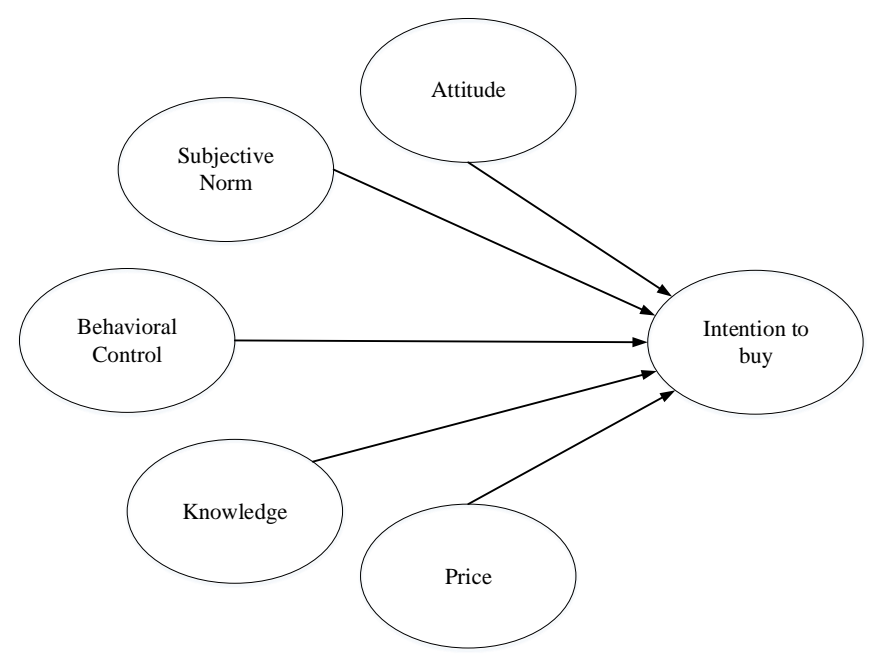

Fig. 1. Conceptual framework of this study.

Five hypotheses (stated below) were developed to test the relationship between dependent variable (purchasing intention of energy-efficient product) and independent variables (attitude, subjective norm, perceived control, knowledge and price). Previous literature supported the directionality in each hypothesis which is based on the TPB model [41]. Thus, this study intends to confirm the direct and positive relationship between attitude, subjective norm, perceived behavioural control, knowledge and price and behavioural intention.

\subsection{Attitude}

Attitude is one of the leading factors in shaping consumers purchase behaviours [42]. Residents with favourable attitude toward energy saving affect intention to buy energy efficient product. Numerous empirical studies confirmed that attitude is considered as an important factor of behavioural intention in various settings i.e. consume sustainable or environmentally friendly foods [43], sustainable food consumption [44]. In addition, some studies have found a particular relationship between attitude and electricity saving intention. Among them Zhang et al. [45] have found significant relationship between attitude and intention to save electricity. Therefore, the following hypothesis is developed:

Hypothesis 1: There is a significant and positive relationship between attitude and intention to purchase energy-efficient household products.

\subsection{Subjective Norm}

Subjective norm is considered as the second independent construct of intention in TPB model. According to Ajzen [16] subjective norm refers to "the perceived social pressure to perform or not to perform the behaviour". Ajzen and Driver [46] reported that normative beliefs is the social factor and basis for subjective norm. Bagozzi et al. [47] called perceived social pressure as the subjective norm which comply with expectations about engaging in the behaviour.

Several other researchers have mentioned subjective norm as important factors of behavioural intention in marketing area and consumers research, such as green product buying behaviour [48], halal food buying intention [49], organic food buying intention [33], [34] and online buying intention [50]. All these studies found significant and positive relationship between subjective norm and 
behavioural intention. This study also hypothesized significant and positive association between subjective norm and intention to purchase energy-efficient household product. For this context, we propose:

Hypothesis 2: There is a significant and positive relationship between subjective norm and intentions to purchase energy-efficient household products.

\subsection{Perceived Behavioural Control}

Perceived behavioural control is the third most important determinants in TPB model. Researchers like Zhang et al. [51] studied in waste separation behaviour, Chang et al. [52], Teng et al. [53], studied in green hotels, Tarkiainen and Sundqvist [54], Thogersen [55] studied in organic foods and Paul et al. [56] confirmed positive and significant association between perceived behavioural control and behavioural intention. Based on the above findings, we can say that consumer will purchase energy-efficient household product when they have enough control about the instant. In this research perceived behavioural control is considered as the ability to purchase energy-efficient product. The third hypothesis proposed here is:

Hypothesis 3: There is a positive and significant association between perceived behavioural control and intention to purchase energy-efficient household products.

\subsection{Knowledge}

Knowledge has significant influence in all phases in the decision-making process [57]. Specifically, knowledge is a relevant and significant construct that affects how consumers gather and organize information [58], how much information is used in decision making [59] and how consumers evaluate products and services [60]. Young et al. [61] study presented environmental knowledge is one of major determinants of green purchase behaviour. Chan and Lau [62] studied in China and used ecological knowledge is one of the predictors in green purchase research. The study results show that the higher ecological knowledge has ultimately influence green purchase behaviour. Wahid et al. [2] and Mei et al. [63] conducted studies on green purchase behaviour using environmental knowledge as one of the predictors and found significant relationship between environmental knowledge and green purchase intention. Therefore, the hypothesis developed is:

Hypothesis 4: There is a positive and significant association between knowledge and intention to purchase energy-efficient household product.

\subsection{Reasonable Price}

Researchers have found significant influence of price and green purchase intention [64]. Other researchers have confirmed that consumers with positive motive would purchase green if manufacturers offer reasonable price for green products [65], [66]. Environmental conscious consumers always buy green products although it is high price. Other studies argued that consumers are willing to pay high price for eco-labelled products [67], [68]. Zhen and Mansori [69] highlighted that consumers are always search for low price for green products when they, but high price for green products will reduce purchase intention. These results support to develop the following hypothesis:

Hypothesis 5: There is a positive and significant association between reasonable price and intention to purchase energy-efficient household products.

\section{RESEARCH DESIGN}

The main objective of this study is to examine and analyse the factors that are influencing household intention to buy energy-efficient products. An empirical study was undertaken to accomplish the objective of this study. This section briefly explains the methodological matters 
related to sample and procedure (section 4.1), measures used (section 4.2), reliability and validity of measures (section 4.3) and multicollinearity and normality of study data (section 4.4).

\subsection{Sample and Procedure}

Residents of Klang Valley in Malaysia were chosen as the sample for this study. Klang Valley consists of Putrajaya, Petaling jaya, Klang, Gombak, Sepang, Ulu Langat in Selangor state. Kuala Lumpur is the capital city and largest city of Malaysia. The main reason is chosen this area as it has the highest population density and urbanisation. Compared to other states in Malaysia it is also has the modern facilities and well equipped.

Initially to test the face validity, the questionnaire was pretested to the faculty members at Faculty of Economics and Management Universiti Kebangsaan Malaysia. On voluntary basis, five faculty members participated and provided constructive suggestions. The final questionnaire was fine-tuned based on the feedbacks given by the pretest samples. The revised questionnaire was then administered to respondents with a cover letter explaining the purpose of the study.

Due to cost and time saving non-probability convenience sampling method was used to in this study. Data was gathered face-to-face. Students from research methods class participated in the data collection process. First, they posted 1000 questionnaires including a cover letter to the respondents. After fifteen days, researcher personally contacted the residents and requested them to participate in the survey. Within one and half month a total of 345 completed questionnaires were received with a response rate of $34.5 \%$. Due to incomplete responses, 9 questionnaires were discarded. Only 336 questionnaires were used for this final analysis.

The highest contributors to the total respondents are represented by young female Malay $(51.01 \%)$, Chinese were $40 \%$, Indian $8.11 \%$ and others $0.88 \%$. Most of the respondents are female $(60.16 \%)$ and most of the them were from the age group between 30-40. Most of the respondents are working full on a time basis $(85.14 \%)$. Majority of respondents received higher education $(75.07 \%), 16.23 \%$ were diploma holder and $8.70 \%$ were other educational background.

\subsection{Measures}

The measurement items of all constructs i.e. attitude, subjective norm, perceived behavioural control and behavioural intention were adopted and modified from the study of Alam and Sauyti [49]. Reasonable price was adopted from the study of Suciarto et al. [70] and knowledge was adopted and modified from the study of Yang [71]. Likert type scale was used $(1=$ strongly disagree to $6=$ strongly agree) in the questionnaire. All items of the constructs shown in Table 1.

\subsection{Reliability, Content Validity and Construct Validity}

Cronbach's Alpha value was used to verify the internal reliability of the items [72]. The Cronbach alpha value for perceived intention was 0.863 attitude is 0.891 , following by subjective norms which was 0.772 , perceived behavioural control was 0.824 , knowledge was 0.759 , and reasonable price was 0.823 . The alpha values for all the constructs are above 0.7 which indicates a reliable consistency among the variables [72].

The questionnaire is developed based on extensive literature review and opinion of experts on the area of study. As suggested by Nunnally [72], content validity represents the adequacy of specific domain of content and comprehensive measure of area under study. The items were adopted and adapted from established literature survey that so that the approach should support the issue of content validity.

Construct validity was tested through exploratory factor analysis (EFA). The EFA test enable the identification of underlying constructs and investigation of relationship between key survey interval- 
scale of questions which in the case of this study is about intent to buy energy-efficient electronic products. In doing so, factoring of principal axis was carried out which continued with varimax rotation (Kaiser-Normalization) to facilitate interpretability. Sampling adequacy were tested using Kaiser-Mayer Olkin measures to determine the suitability of using factor analysis. Only factors that hold eigenvalues of more than 1.0 should be retained and below that to be dropped. The test yielded a total of 5 factors with eigenvalue of more than 1.0 explaining $59.32 \%$ of the total variance. The combined results of factors analysis on five conditions for energy efficient product buying intention was considered in this study indicating all items loaded on their expected factors (Table 1).

\section{TABLE 1. FACTOR ANALYSIS AND RELIABILITY}

\begin{tabular}{|c|c|c|}
\hline Attitude & & 0.891 \\
\hline I like the idea of buying energy efficient household products & 0.654 & \\
\hline I think that buying energy efficient household product is a good idea & 0.712 & \\
\hline I have favourable attitude toward energy efficient household products & 0.687 & \\
\hline Subjective Norm & & 0.772 \\
\hline $\begin{array}{l}\text { People who influence my behaviour would think that I should buy energy } \\
\text { efficient household products }\end{array}$ & 0.725 & \\
\hline My close friends think that I should buy energy efficient household products & 0.670 & \\
\hline $\begin{array}{l}\text { Most of the people who are important to me think I should buy energy } \\
\text { efficient household products }\end{array}$ & 0.734 & \\
\hline Perceived Behavioural Control & & 0.824 \\
\hline $\begin{array}{l}\text { I will buy energy efficient household products even my friends advise me } \\
\text { not to use }\end{array}$ & 0.679 & \\
\hline Buying energy efficient household products is entirely within my control & 0.652 & \\
\hline I have resources and ability to buy energy efficient household products & 0.698 & \\
\hline Knowledge & & 0.759 \\
\hline I have sufficient knowledge about energy efficient product & 0.625 & \\
\hline $\begin{array}{l}\text { I have knowledge about energy efficient product is based on previous } \\
\text { experience }\end{array}$ & $\begin{array}{l}0.761 \\
0.693\end{array}$ & \\
\hline \multicolumn{3}{|l|}{ I have a positive impression about energy efficient product } \\
\hline Reasonable Price & & 0.823 \\
\hline The price for energy efficient household products impulse me to buy & 0.683 & \\
\hline $\begin{array}{l}\text { The price for energy efficient household product is too high for me to buy }{ }^{\circledR} \\
\text { I think low price is for buying energy efficient household products }\end{array}$ & 0.691 & \\
\hline $\begin{array}{l}\text { The price of energy efficient household products are affordable to buy for } \\
\text { me }\end{array}$ & 0.726 & \\
\hline Buying Intention & & 0.863 \\
\hline I intend to buy energy efficient household products & 0.867 & \\
\hline I intend to buy energy efficient household products regularly in future & 0.876 & \\
\hline $\begin{array}{l}\text { I would highly recommend buy energy efficient household products for } \\
\text { other people to use }\end{array}$ & 0.868 & \\
\hline
\end{tabular}

\subsection{Normality of Data and Multi-Collinearity}

Central Theorem is applied in this study based on the large sample (336 samples) therefore the issues of data normality is mitigated. In addition, two major methods; a) Tolerance test, and b) Variance Inflation Factor (VIF) were utilized in determining the multicollinearity between independents variables in this study [74]. In the Table 2 shown that: a) tolerance values are not less than 0.1 and b) VIF values are less than 10. Based on the results it can be conclude that 
multicollinearity is not the problem in this study. The value between 1.5 and 2.5 is considered as the acceptable for Durbin-Watson range. Regression results show that the Durbin-Watson value is 1.917 which confirmed there is no auto correlation problems in our data which has used in this study. Thus, it can be concluded that multicollinearity is not an issue.

TABLE 2. TEST OF COLLINEARITY

\begin{tabular}{lll}
\hline Variables & Tolerance & VIF \\
\hline Attitude & 0.702 & 1.424 \\
Subjective norm & 0.723 & 1.323 \\
Perceived behavioural & 0.780 & 1.283 \\
control & 0.792 & 1.541 \\
Knowledge & 0.735 & 1.436 \\
Reasonable Price & & \\
\hline
\end{tabular}

\section{HYPOTHESIS TESTING}

In Table 3 multiple regression results show the strength of proposed hypothetical relationships. Based on the guidelines by Hair et al. [73] hypotheses were tested using a multiple regression analysis, where energy-efficient household products buying intention was the dependent variable. The analysis results found is shown in Table 3. The research results show that in the prediction model all hypotheses were found to be positive and significant. The results provide support for hypotheses $\mathrm{H} 1, \mathrm{H} 2, \mathrm{H} 3, \mathrm{H} 4$ and $\mathrm{H} 5$ where the following were observed: relationship between attitude and purchase intention $(\beta=0.371 ; p<0.001)$, subjective norm on energy-efficient product purchasing intention $(\beta=0.371 ; p<0.001)$, perceived behavioural control on energy-efficient product $(\beta=0.411 ; p$-value $<0.001)$, knowledge on energy-efficient product purchasing intention $(\beta=0.486 ; p$-value $<0.001)$ and reasonable price on energy-efficient product buying intention $(\beta=0.468 ; p$-value $<0.001)$.

\section{TABLE 3. REGRESSION RESULTS (DEPENDENT VARIABLE: ENERGY-EFFICIENT} HOUSEHOLD PRODUCT BUYING INTENTION, $P<0.01$ )

\begin{tabular}{llll}
\hline Variables & Beta & $t$-value & $p$-value \\
\hline Attitude & 0.371 & 3.955 & $0.000^{* * * *}$ \\
Subjective norm & 0.371 & 3.960 & $0.000^{* * * *}$ \\
$\begin{array}{l}\text { Perceived behavioural } \\
\text { control }\end{array}$ & 0.411 & 4.469 & $0.000^{* * *}$ \\
Knowledge & 0.486 & 5.498 & $0.000^{* * *}$ \\
Reasonable price & 0.468 & 5.241 & $0.000^{* * *}$ \\
\hline$* * * p<0.001$ & & &
\end{tabular}

Extended TPB model was examined in this research, in which environmental knowledge and reasonable price were the two additionally variables introduced. The main objective of this study was to investigate Malaysian consumers' energy-efficient product buying intention. The results of this study suggested that consumers' buying intention of energy-efficient product can be predicted by TPB factors (attitude, subjective norm, perceive control), environmental knowledge and reasonable price. 
Consistent with previous studies, this study confirms the positive and significant association between attitude and energy-efficient product buying intention. Previous studies highlighted that attitude has significant effect and play important role on consumer's buying intention [75]. Another study also confirmed that attitude has positive relationship between behavioural intentions in different cultures [76]. Due to the high social pressure favourable attitude on buying intention of energy-efficient product was found in this study.

Support from previous study by Karajin et al. [77], this research also confirms that subjective norm has significant and positive associations with intention to purchase energy-efficient product in Malaysia. Other researcher also supported that subjective norm one of the important predictors of purchase intentions [78]. In Western culture people are individualistic and they think they are independent and autonomous, in which behavioural decision is affected by independent decision. Whereas, in Muslim culture in Malaysia, people tend to behave as a group and interdependent. This holds true for a collectivistic country like Malaysia.

According to Ajzen [17], in TPB model, perceived behavioural control has a direct relationship on behavioural intention. This study found a positive and significant relationship between perceived behavioural control and energy-efficient product buying intention. Previous studies have concluded similar findings [79].

Notably, examination of the relative strengths of the associations between the individual independent variables and energy-efficient household product purchase intention noticeably indicate that knowledge and reasonable price can explain the variation in energy-efficient household products purchasing intention [2], [63], [68]. In other words, those using energy-efficient household products, the perception of knowledge and reasonable price are the better predictors relating to energy-efficient product purchase intention.

\section{Conclusions}

This research result highlights some implications that may help in formulating strategies for energy-efficient products production and customers' buying intentions. Attitude, subjective norm, perceived behavioural control, environmental knowledge and reasonable price had significant effect on buying intention with environmental knowledge having a strongest influence, followed by reasonable price, perceived behavioural control, subjective norm and finally attitude. Due to environmental issues and price, Malaysian consumers' have given full attention towards energyefficient products. So it can be implied that, consumers in Malaysia are more concerned about the environmental degradation and cost of energy. If quality and performance of energy-efficient products are good, more consumer will purchase energy-efficient products. This study results also confirmed that consumers may decide to buy energy-efficient product because it will reduce energy cost and good for their heath. Finally, it can also be concluded that Malaysians are motivated to behave environmentally friendly.

It is evident that in future energy-efficient household products will have higher demand and growth potential. Which means that energy-efficient product certification is important in Malaysia. This could lead to a growth in demand for energy-efficient certification. Hence, it could be suggested that and independent body should be established to audit energy-efficient products. The independent body can assist consumers in verifying the environmental claims, manage energy-efficient household products label and perhaps audit the energy-efficient household products procedures to ensure that these products meet acceptable quality standards. 


\section{REFERENCES}

[1] Ali A., Khan A. A., Ahmed I. Determinants of Pakistani Consumers' Green Purchase Behaviour: Some insights from a developing country. International Journal of Business and Social Science 2011:2(3):217-226.

[2] Wahid N. A., Rahbar E., Tan S. S. Factors Influencing the Green Purchase Behavior of Penang Environmental Volunteers. International Business Management 2011:5(1):38-49. doi:10.3923/ibm.2011.38.49

[3] Paco A. M. F., Raposo M. "Green" segmentation: An application to the Portuguese consumer market. Marketing Intelligence and Planning 2009:27(3):364-379. doi:10.1108/02634500910955245

[4] Barber N. "Green" wine packaging: Targeting environmental consumers. International Journal of Wine Business Research 2010:22(4):423-444. doi:10.1108/17511061011092447

[5] Okada E. M., Mais E. L. Framing the "Green" alternative for environmentally conscious consumers, sustainability accounting. Management and Policy Journal 2010:1(2):222-234. doi:10.1108/20408021011089257

[6] Bryunina D., Khodadad S. S. The Influence of Eco-labeled Products on Consumer Buying Behavior by focusing on eco-labeled bread [Online]. [Accessed 24.10.2016]. Available: http://mdh.diva-portal.org/smash/get/diva2:390922/FULLTEXT01.pdf

[7] Mainieri T., Barnett E. G., Valdero T. R., Unipan J. B., Oskamp S. Green Buying: The Influence of Environmental Concern on Consumer Behavior. Journal of Social Psychology 1997:137(2):189-204. doi.org/10.1080/00224549709595430

[8] Chen T. B., Chai L. T. Attitude towards the environment and green products: Consumers perspective. Management Science and Engineering 2010:4(2):27-39. doi.org/10.3968/j.mse.1913035X20100402.002

[9] Vaghefi N., Siwar C., Aziz S. A. A. G. Green GDP and Sustainable Development in Malaysia. Current World Environment 2015:10(1):1-8. doi:10.12944/CWE.10.1.01

[10] Yunus R. Malaysia's annual energy usage to increase $4.8 \%$ by 2030 [Online]. [Accessed 8.02.2019]. Available: https://themalaysianreserve.com/2017/11/14/malaysias-annual-energy-usage-increase-4-8-2030

[11] Leelakulthanit O. The Factors Affecting the Adoption of LED Lamps. International Business \& Economics Research Journal 2014:13(4):757-767. doi:10.19030/iber.v13i4.8684

[12] Shila S. The impact of individual differences on green purchasing of Malaysian consumers. International Journal of Business and Social Science 2012:3(16):132-140.

[13] Zainudin N. Attitudes Towards Energy Efficient Products: the Influence of Eco-Literacy and Social Influence. Wick E-Journal of Integration Knowledge 2013:117-124:473-480.

[14] Moisander J. Motivation complexity of green consumerism. International Journal of Consumer Studies 2007:31(4):404-9. doi:10.1111/j.1470-6431.2007.00586.x

[15] Ajzen I., Madden T. J. Prediction of goal directed behavior: Attitudes, intentions and perceived behavioral control. Journal of Experimental Social Psychology 1986:22(5):453-474. doi:10.1016/0022-1031(86)90045-4

[16] Ajzen I., Fishbein M. The prediction of behavior from attitudinal and normative variables. Journal of Experimental Social Psychology 1970:6(4):466-487. doi:10.1016/0022-1031(70)90057-0

[17] Ajzen I. Theory of planned behavior. Organization Behavior and Human Decision Process 1991:50(2):179-211. doi:10.1016/0749-5978(91)90020-T

[18] Robinson R., Smith C. Psychosocial and Demographic Variables Associated with Consumer Intention to Purchase Sustainably Produced Foods as Defined by the Midwest Food Alliance. Journal of Nutrition Education and Behavior 2002:34(6):316-325. doi:10.1016/S1499-4046(06)60114-0

[19] Davis F. D., Bagozzi R. P., Warshaw P. R. User acceptance of computer technology: a comparison of two theoretical models. Management science 1989:35(8):982-1003. doi:10.1287/mnsc.35.8.982

[20] Armitage C. J., Corner M. Efficacy of the theory of planned behaviour: A meta-analytic review. British Journal of social psychology 2001:40(4):471-499. doi:10.1348/014466601164939

[21] Russo D. A., Stochl J., Painter M., Shelley G. F., Jones P. B., Perez, J. Use of the Theory of Planned Behaviour to assess factors influencing the identification of students at clinical high-risk for psychosis in 16+ Education. BMC Health Services Research 2015:15:411. doi:10.1186/s12913-015-1074-y

[22] Taylor S., Todd, P. Understanding the determinants of consumer composting behavior. Journal of Social Applied Psychology 1997:27(7):602-628. doi:10.1111/j.1559-1816.1997.tb00651.x

[23] Thompson K. E., Hazins N., Alekas P. J. Attitude and food choice behavior. British Food Journal 1994:96(11):9-13. doi: $10.1108 / 00070709410074632$

[24] Conner M., Sparks P. The theory of planned behaviour and health behaviours. Predicting Health Behaviour. Buckimgham: Open University Press, 1996.

[25] Sparks P., Shephard R. Self-identity and the theory of planned behavior: Assessing the role of identification with "Green consumerism". Social Psychology Quarterly 1992:55(4):388-399. doi:10.2307/2786955

[26] Honkanen P., Olsen S. O., Verplanken B. Intention to consume seafood- the importance of habit. Appetite 2005:45(2):161-168. doi:10.1016/j.appet.2005.04.005

[27] Verbeke W., Vermeir I., Vackier I. Impact of values, involvement and perceptions on consumer attitudes and intentions towards sustainable food consumption. Journal of Agricultural and Environmental Ethics 2006:19(2):1569-1594. 
[28] Cook A. J., Fairwheather J., Campbell H. New Zealand farmer and grower Intentions to use genetic engineering technology and organic methods. Cantebury: Agribusiness and Economics Research Unit Lincoln University, 2000.

[29] Sparks P., Shepherd R., Frewer L. J. Assessing and structuring attitudes towards the use of gene technology in food production: the role of ethical obligation. Basic and Applied Social Psychology 1995:16(3):267-285. doi:10.1207/s15324834basp1603_1

[30] Bonne K. Vermeir I. Bergeaud-Blackler F., Verbeke W. Determinants of halal meat consumption in France. British Food Journal 2007:109(5):367-386. doi:10.1108/0070700710746786

[31] Maichum K., Parichatnon S., Peng K.-C. Application of the Extended Theory of Planned Behavior Model to Investigate Purchase Intention of Green Products among Thai Consumers. Sustainability 2016:8(10):1-20. doi:10.3390/su8101077

[32] Paul J., Modi A., Paten J. D. Predicting green product consumption using theory of planned behavior and reasoned action. Journal of Retailing and Consumer Services 2016:29:123-134. doi:10.1016/j.jretconser.2015.11.006

[33] Urban J., Zverinova I., Scasny M. What Motivates Czech Consumers to Buy Organic Food? Czech Sociological Review 2012:48(3):509-536.

[34] Irianto H. Consumers' Attitude and Intention towards Organic Food Purchase: An Extension of Theory of Planned Behavior in Gender Perspective. International Journal of Management, Economics and Social Sciences 2015:4(1):17-31.

[35] Ranadive A. An Empirical Study on the Online Grocery Shopping Intentions of Consumers in Vadodara City. International Journal of Management and Social Sciences Research 2015:4(3):8-14.

[36] Al-Azzam A. F. M. Evaluating the antecedents of online consumer purchasing behavior: an empirical study based on the Theory of Planned Behavior. International Journal of Economics, Commerce and Management 2014:11(4):1-18.

[37] Nchise A. An Empirical Analysis of the Theory of Planned Behavior: A Review of Its Application on E-democracy Adoption Using the Partial Least Squares Algorithm. JeDEM 2012:4(2):171-182. doi:10.29379/jedem.v4i2.129

[38] Kim Y. G, Jang S. Y., Kim A. K. Application of the theory of planned behavior to genetically modified foods: Moderating effects of food technology neophobia. Food Research International 2014:62:947-954. doi:10.1016/j.foodres.2014.03.057

[39] Conner M., Armitage C. J. Extending the theory of planned behaviour: A review and avenues for further research. Journal of Applied Social Psychology 1998:28(15):1429-1464. doi:10.1111/j.1559-1816.1998.tb01685.x

[40] Karatu V. M. H., Mat N. M. N. The Mediating Effects of Green Trust and Perceived Behavioral Control on the Direct Determinants of Intention to Purchase Green Products in Nigeria. Mediterranean Journal of Social Sciences 2015:6(4):256-265. doi:10.5901/mjss.2015.v6n4p256

[41] Eze U. C., Ndubisi N. O. Green Buyer Behavior: Evidence from Asia Consumers. Journal of Asian and African Studies 2013:48(4):413-426. doi:10.1177/0021909613493602

[42] Cazacu S., Rotsios K., Moshonas G. Consumers' Purchase Intentions towards Water Buffalo Milk Products (WBMPs) in the Greater Area of Thessaloniki, Greece. Procedia Economics and Finance 2014:9:407-416. doi:10.1016/S22125671(14)00042-2

[43] Pavlou P. A. What drives electronic commerce? A theory of planned behavior perspective. Academy of Management Annual Meeting Proceedings 2002:1:81-85. doi:10.5465/APBPP.2002.7517579

[44] De Barcellos M. D., et al. Investigating the gap between citizens' sustainability attitudes and food purchasing behaviour: empirical evidence from Brazilian pork consumers. International Journal of Consumer Studies 2011:35:391-402. doi:10.1111/j.1470-6431.2010.00978.x

[45] Zhang Y., Wang Z., Zhou G. Determinants of employee electricity saving: the role of social benefits, personal benefits and organizational electricity saving climate. Journal of Cleaner Production 2013:66:280-287. doi:10.1016/j.jclepro.2013.10.021

[46] Ajzen I., Driver B. L. Prediction of leisure participation from behavioral, normative, and control beliefs: An application of the theory of planned behavior. Leisure Sciences 1991:13:185-204. doi:10.1080/01490409109513137

[47] Bagozzi R. P., Wong N., Abe S., Bergami M. Cultural and situational contingencies and the theory of reasoned action: Application to fast food restaurant consumption. Journal of Consumer Psychology 2000:9(2):97-106. doi:10.1207/S15327663JCP0902 4

[48] Hsu Y.-C. P., Chan F. Surveying Data on Consumer Green Purchasing Intention: A Case in New Zealand. International. Journal of Business and Social Research 2015:5(5):1-14. doi:10.18533/ijbsr.v5i5.756

[49] Alam S. S., Sayuti N. M. Applying Theory of Planned Behavior (TPB) in Halal Food Purchasing. International Journal of Commerce and Management 2011:21(1):8-20. doi:10.1108/10569211111111676

[50] Lin H.-F. Predicting consumer intentions to shop online: An empirical test of competing theories. Electronic Commerce Research and Applications 2007:6:433-442. doi:10.1016/j.elerap.2007.02.002

[51] Zhang D., Huang G., Yin X., Gong Q. Residents' Waste Separation Behaviors at the Source: Using SEM with the Theory of Planned Behavior in Guangzhou, China. International Journal of Environmental Research and Public Health 2015:12:9475-9491. doi:10.3390/ijerph120809475

[52] Chang L., Tsai C., Yeh S. Evaluation of green hotel guests' behavioral intention. Advances in Hospitality and Leisure 2014:10:75-89. doi:10.1108/S1745-354220140000010004 
[53] Teng Y.-M., Wu K.-S., Liu H.-H. Integrating altruism and the theory of planned behaviour to predict patronage intention of a green hotel. Journal of Hospitality and Tourism Research 2014:39(3):299-315 doi:10.1177/1096348012471383

[54] Tarkiainen A., Sundqvist S. Subjective norms, attitudes and intentions of Finnish consumers in buying organic food. British Food Journal 2005:107(10/11):808-822. doi:10.1108/00070700510629760

[55] Thøgersen J. Consumer decision making with regard to organic food products. Traditional food production facing sustainability: A European challenge. Ashgate: Farnham, 2007.

[56] Paul J., Modi A., Patel J. Predicting green product consumption using theory of planned behavior and reasoned action. Journal of Retailing and Consumer Services 2016:29:123-134. doi:10.1016/j.jretconser.2015.11.006

[57] Nor N. A. M., Muhammad A., Kassim A., Jamil C. Z M., Mat N., Salleh H. S. Creating Green Consumer: How Environmental Knowledge and Environmental Attitude Lead to Green Purchase Behaviour? International Journal of Arts \& Sciences 2012:5(1):55-71.

[58] Alba J. W., Hutchinson J. W. Dimensions of consumer expertise. Journal of Consumer Research 1987:13:411-454. doi: $10.1086 / 209080$

[59] Brucks M. The effects of product knowledge on information search behaviour. Journal of Consumer Research 1985:12(6):1-16. doi:10.1086/209031

[60] Murray K. B., Schlacter J. L. The Impact of Services Versus Goods on Consumer's Assessment of Perceived Risk and Variability. Journal of the Academy of Marketing Science 1990:18(1):51-65. doi:10.1007/BF02729762

[61] Young W., Hwang K., Mcdonald S., Oates C. J. Sustainable Consumption: Green Consumer Behaviour when Purchasing Products. Sustainable Development 2009:18(1):21-31. doi:10.1002/sd.394

[62] Chan R. Y. K., Lau L. B. Y. Antecedents of green purchase: A survey in China. Journal of Consumer Marketing 2000:17(4):338-357. doi:10.1108/07363760010335358

[63] Mei O. J. Ling K. C., Piew T. H. The Antecedents of Green Purchase Intention among Malaysian Consumers. Asian Social Science 2012:8(13):248-263. doi:10.5539/ass.v8n13p246

[64] Lee C., H., Ling H. Y., Yeow J., Hasan A., Arif M. The Influence of Green Consumption Cognition of Consumers on Behavioral Intention-A case study of the Restaurant Service Industry. African Journal of Business Management 2011:6(26):7888-7895.

[65] Ansar N. Impact of Green Marketing on Consumer Purchase Intention. Mediterranean Journal of Social Sciences 2013:4(11):650. doi:10.5901/mjss.2013.v4n11p650

[66] Ali A., Ahmad I. Environmental Friendly Products: Factors that Influence the Green Purchase Intention of Pakistan Consumers. Pakistan Journal of Engineering Technology Science 2012:2(1):84-117. doi:10.22555/pjets.v2i1.697

[67] Bigsby H., Ozanne L. C. The purchasing decision: Consumers and environmentally certified wood products. Forest Product Journal 2002:52(7/8):100-105.

[68] Vlosky R. P., Ozanne L. K., Fontenot, R. J. A conceptual model of US consumer willingness-to-pay for environmentally certified wood products. The Journal of Consumer Marketing 1999:16(2):122-136. doi: $10.1108 / 07363769910260498$

[69] Zhen J. S. S., Mansori S. Young Female Motivation for Purchase of Organic. Food in Malaysia. International Journal of Contemporary Business Studies 2012:3(5):61-72.

[70] Suciarto S. A., et al. Influence of Green Marketing toward Purchase Intention of Green Products through Attitude: Survey on Indonesian and Taiwanese Students. International Journal of Humanities and Management Sciences 2015:3(4):198-202.

[71] Yang M. Consumer Attitude and Purchase Intention towards Organic Food - A quantitative study of China, an unpublished Master thesis. Linnaeus: Linnaeus University, 2014.

[72] Nunnally J. C. Psychometric Theory. New York: McGraw-Hill, 1978.

[73] Hair J. F. Anderson R. E. Black W. C. Multivariate Data Analysis. New Jersey: Prentice-Hall, 1998.

[74] Kleinbaum D. G., Kupper L. L., Muller K. E. Applied Regression Analysis and Other Multivariate Medhods. Boston: PWS, 1988.

[75] Tsen C.-H., Phang G., Hasan H., Buncha M. R. Going green: A study of consumers' willingness to pay for green products in kota kinabalu. International Journal of Business and Society 2006:7:40-54.

[76] Mostafa M. M. A hierarchical analysis of the green consciousness of the Egyptian consumer. Psychol. Mark. 2007:24(5):445-473. doi.org/10.1002/mar.20168

[77] Karajin B., Iris V. Determinants of halal meat consumption in France. British Food Journal 2007:109(5):367-386. doi.org/10.1108/0070700710746786

[78] Kamariah N., Muslim N. The Application of Theory of Planned Behaviour (TPB) in Internet Purchasing: Using SEM. Presented at the International Conference on Marketing and Retailing, Petaling Jaya, Selangor, Malaysia, 2007.

[79] Bonne K., Verbeke W. Muslim consumer's attitude towards meat consumption in Belgium: insights from a means-end chain approach. Anthropology of Food 2006:5. 


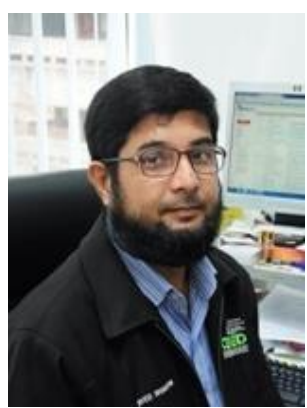

Dr. Syed Shah Alam is an Associate Professor at the Faculty of Business, Finance and Hospitality, Mahsa University Malaysia. Prior to joining to the Mahsa University Malaysia, he taught at Universiti Kebangsaan Malaysia (The National University of Malaysia), Universiti Teknologi MARA (UiTM), Malaysia and Multimedia University Malaysia (MMU). Dr Alam is the recipient of an "Excellent Service Award" at the Universiti Kebangsaan Malaysia in 2011.

He has authored for four books and more than 100 academic articles in business and Ecommerce area. Over the past 5 years he has been actively involved in social enterprises development program in Malaysia with a special interest in participatory action research and social enterprises projects. He focuses on developing and promoting linkages and collaborative social enterprises activities between Malaysian educational and other institutions. He has served as the secretary for "First International Research Conference on Social Business' 2013" held in Universiti Kebangsaan Malaysia.

ORCID ID: https://orcid.org/0000-0002-3402-5041

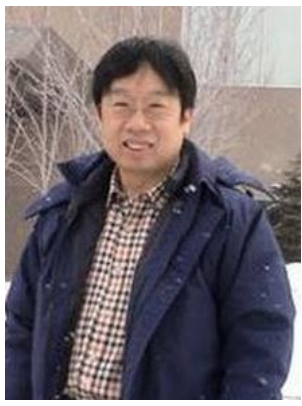

Chieh-Yu Lin received his Ph. D. degree at National Cheng Kung University in Taiwan. He is Professor of the Department of International Business at Chang Jung Christian University, and now is the Dean of the College of Management and Dean of International School of Business. He also served as the Evaluator at the Higher Education Evaluation \& Accreditation Council of Taiwan. Dr. Lin has published a number of articles in several academic journals and international conferences. His publications focus on environmental management, business ethics and corporate social responsibility. Dr. Lin has also conducted several projects of related topics sponsored by the Ministry of Science and Technology in Taiwan. Email: jylin@mail.cjcu.edu.tw

ORCID ID: https://orcid.org/0000-0002-4269-3234

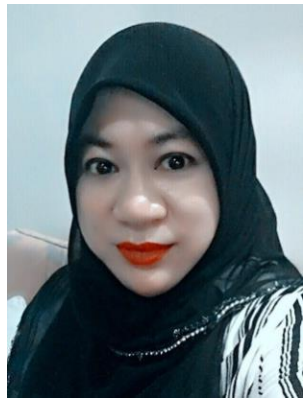

Dr. Maisarah Ahmad is an Associate Professor of Marketing, Management and Humanities Department, Faculty of Science and Information Technology, Universiti Teknologi Petronas. Prior assuming her current post, she was the first to lead the newly incepted Income Generation and Business Development Department under the Pro Vice Chancellor's Office Universiti Kebangsaan Malaysia (UKM), who took up her post on the $15^{\text {th }}$ of October 2015. Prior to her appointment as Executive Deputy Director, she was the Deputy Dean for Research, Innovation and Industry Engagement, Faculty of Economics and Management.

Dr. Maisarah also heads the Consumer and Consumerism Research CoRE-UKM and serves as a Deputy Treasurer for Malaysian Consumer and Family Economics Association (MACFEA) and a member of Consumer Forum Malaysia within the purview of Malaysian Communications and Multimedia Commission, Ministry of Communication and Multimedia. Maisarah is also an Honorary Professor of Marketing, an appointment by the Government of Cambodia for IIC University of Technology Cambodia. Her research passion is predominantly in areas of consumer insights in particular where marketing concepts and theories are fused into nonbusiness context such as recycling, food security and religion, to name a few. Uncovering and exploring consumer socialization is another passion of hers. She has published numerous articles and books on related matters. Email: maisarah.ahmad@utp.edu.my

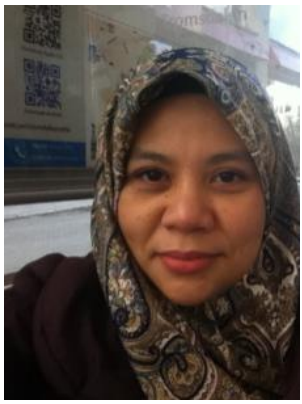

Dr. Nor Asiah Omar an Associate Professor at the Faculty of Economics and Management, The National University of Malaysia (UKM). She has authored more than 40 academics and professional articles in the reputed journal and international conferences. Besides academic research involvement, she also actively involved in contract research involving SMEs and retail industry. She has 20-year experiences of working in the academic world and teaches mainly marketing, innovation and research methodology courses at the undergraduate as well as postgraduate levels.

Email: norasiah@ukm.edu.my

ORCID ID: https://orcid.org/0000-0003-2599-7727 


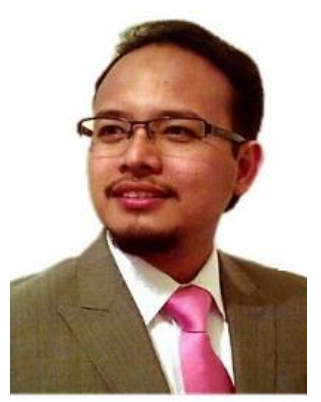

Dr. Mohd Helmi Ali is a Senior Lecturer at the Faculty of Economics and Management, The National University of Malaysia. He holds Bachelor of Management Technology (Maritime Transporation) from Malaysia Maritime Academy, Master of Business Administration from Universiti Putra Malaysia, and a Ph. D. Business and Management, University of Nottingham, United Kingdom. He has experiences in multiple industries such as food, oil and gas, maritime, transportation, and construction. Despite of his recent involvement in academics, he has worked with many research grants, in particular on supply chain and sustainability. His research interest focuses on food integrity, halal food supply chain, sustainable development, operations management and innovation.

ORCID ID: https://orcid.org/0000-0002-2774-2659 